\title{
FILM RATING: A COMPARATIVE ANALYSIS IN MALAYSIA AND BANGLADESH
}

\section{Md. Zahidul Islam}

Ahmad Ibrahim Kulliyyah of Laws (AIKOL),

International Islamic University Malaysia (IIUM).

Malaysia.

*Corrosponding author's Email: zahidul@iium.edu.my

Author's Biography

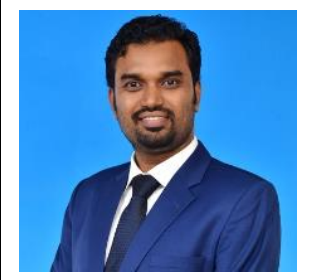

Dr. Md. Zahidul Islam has completed Pd.D, at the Ahmad Ibrahim Kulliyyah (faculty) of Laws, International Islamic University Malaysia (IIUM). He received his legal education in Bangladesh and Malaysia. He has achieved valuable experience in research work. Based on research evaluations, he was honored the IIUM Postgraduate Niche Area Scholarship (2013/2014) and President Scholarship (2014/2015). The author has written articles on issues on Human Rights law and media law in local and international journals. He has also attended several local and international Conferences. Currently, He is working as an assistant professor at Ahmad Ibrahim Kulliyyah (faculty) of Laws, International Islamic University Malaysia (IIUM). Email: zahidulislamiium@yahoo.com.

Peer-review under responsibility of $3^{\text {rd }}$ Asia International Multidisciplanry Conference 2019 editorial board (http://www.utm.my/asia/our-team/) (C) 2019 Published by Readers Insight Publisher, lat 306 Savoy Residencia, Block 3 F11/1,44000 Islamabad. Pakistan, info@ readersinsight.net This is an open access article under the CC BY-NC-ND license (http://creativecommons.org/licenses/by-nc-nd/4.0/). 


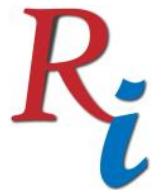

\section{Asia Proceedings of Social Sciences}

(APSS)

www.readersinsight.net/APSS

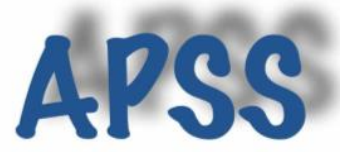

\section{Rese a r ch H i g h I igh t s}

Film rating is a form of censorship where restrictions are imposed on the population on what films a person could view. In some instances the rating of films may result to a failure of a film producer to recoup his investment in the film. However, some view rating system as a guideline for individuals or parents or guardians to decide which films should they or person under their care view.

\section{Research Objectives}

The main purpose of this paper is to discuss the legal framework of film rating and current film rating process of Malaysia and Bangladesh. This paper also try to indentify the strengths and weaknesses of film rating process of both countries.

\section{Methodology}

The researcher mainly adopted qualitative methods. The information has taken from many readings, articles, books, newspapers and statutes. The researcher also conducted interview with the member of the film censorship board, directors and actors of both countries. For this, the researcher used semi-structured form of interview.

\section{Results}

The film censorship laws in Malaysia can be found in two main regulations which are (a)Film Censorship Act 2002 and (b) Film Censorship Guideline of 2010. According to film censorship law, films approved by the Film Censorship Board are classified into three categories, namely: U; P13; and 18 as follows:

U-This category is for viewing by all walks of life without age limit. The film potrays good values, decency and positive lessons as well as entertaining.

P13-Viewers under 13 years of age need parental/guardian supervision while viewing. Scenes in the film consists elements of horror; scary; negative acts; suspense and frantic elements, but not excessive; elusive storyline; and elements that can disturb a child's emotion.

18-This category is for viewers aged 18 and above. The film contains elements of horror, gory, and violent, but not excessive; adult scene that is not excessive; social, sensitive political and religious elements which require a high level understanding.

On the other hand, the film censorship laws in Bangladesh can be found in three main regulations which are (a) Censorship of Film Act 1963, (b) Bangladesh Censorship of Films Rules 1977 and (c) Code for Censorship of Films 1985. According to film censorship law, Film Censorship Board are classified into two categories, namely: U and A as follows:

U- This category is for viewing by all walks of life without age limit. The film potrays good values, decency and positive lessons as well as entertaining.

A- This category is for viewers aged 18 and above.

\section{Findings}

People in the film industry in both countries accepted the need for film rating as guidance for individuals and parents in choosing film viewing. However, their disagreement with the current system is the amount of restrictions still being imposed for the "18" rating. Perhaps more leeway should be given to the content of the film in the " 18 " rating particularly thematic and socio-political content of the films. 


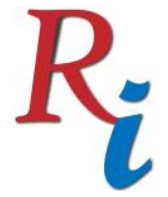

\section{Asia Proceedings of Social Sciences}

(APSS)

www.readersinsight.net/APSS

For Bangladesh, the limited categories of only " $U$ " and " $A$ " may require expansion of the categories. If we consider the views from Malaysia, children may be categorised between primary school children and secondary school children with different developmental stage. Thus, at least Bangladesh could add another rating of P13.

\section{References}

Guan, S. T. (2015). Film Censorship in the Asia-pacific Region. Routledge.

Hamzah, A., \& Mustafa, S. E. (2008). Drama products and copyright issues in Malaysia.

Izani, M., \& Eshaq, A. R. (2003, August). Analysis of the keyframe animation and motion capture case studies. In Proceedings. Student Conference on Research and Development, 2003. SCORED 2003. (pp. 177182). IEEE.

Mahmud, S., Rakib, M. G., Rahman, M. I., \& Hossain, M. M. Present Scenario and Possible Scope of Film Industry: a Case Study on Bangladeshi Film (Dhallywood).

Sridhar, B. S., \& Sridhar, S. (1993). Rating of Instructional Films in Management. Journal of Education for Business, 68(5), 267-272. 